\title{
煩粘膜扁平上皮癌由来細胞株によろインターロイキン-1栐物䓄の産生
}

\author{
宮内忍・諸山隆正・謧田和竞
}

\section{Production of Interleukin-1 like factor by human tumor cell line established from squamous cell carcinoma of the buccal mucosa}

\author{
Shinobu MiYauchI - Takamasa Moroyama - Kazuaki TAKadA
}

\begin{abstract}
The new cell line (Nakata-1) was established from squamous cell carcinoma of the buccal mucosa. IL-1 activity was found in its culture supernatants by thymocyte proliferation assay and fibroblast proliferation assay.

This activity revealed the same behavior as that of human macrophage IL-1 in gel filtration chromatography. This activity, therefore, is thought to be attributed to the so-called "IL-1 like factor."
\end{abstract}

Key words: Interleukin-1, squamous cell carcinoma, cultured cell line

舶



近年, 畽瘍細胞がトランスフォーミンククロースフォ クター1 3), 癌由来血管新生因子()，インスリン様成長因 子 ${ }^{5,6)}$ 等の液性因子を産生するといら多くの報告がみら れる. 一方,インターロイキン-1 (IL-1) は, マクロフォ 一ジの産生する液性因子の 1 つであり, 炎症反応・兔度 反応において重要な役割を果しているが7,8), 同様の物

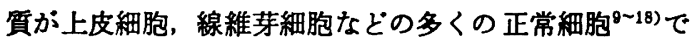
あ産生されることが示されている。しかし, 覀性腫瘍細 胞においては扁平上皮癌息,20), メラノーマ 例で報告されているのみである，畽瘍細胞が，抗腫場作 用を持つ IL-1 を産生する可能性のあることは非常に興 味あることである。

今回われわれは，ヒト頼粘膜扁平上皮癌由来細胞 (Nakata-1)の培養侏化に成功し,その培養上清中の IL-1 活性について検索を行ったので報告する.

\section{材料ならびに方法}

\section{1. 培莠材料}

患者は歳の男性で昭和61年 2 月ロ日, 右側頓粘膜部

厷島大学觜学部口腔外科学第 1 教室

（主任：高田和彰教授）

The First Department of Oral and Maxillofacial Surgery, Hiroshima University, School of Dentistry (Chief: Prof. Kazuaki Takada)

受付日：昭和62年 9 月 2 日
の腫瘤形成を主訴に厇島大学齿学部初䊽

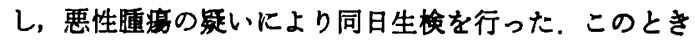
採取した原発部腫瘦組織より無菌的に $5 \mathrm{~mm}$ 角大の材 料を採取し初代培剘を行った。

\section{2. 培答液}

細胞株の樹立には, Dulbecco's Modified Eagle Medium と Ham F 12 Medium (日水製薬 K.K.) を等 量混和し, ベニシリン $(90 \mu \mathrm{g} / \mathrm{ml})$, 重炭酸ナトリウム $(1.4 \mathrm{mg} / \mathrm{ml}), 10 \%$ 牛胎览血清 (FBS, M.A. Bioproduct, USA) を加えた培養液（DME/F-12）を用いた. その他の培菱は, DMEM にペニシリン, 重炭酸ナトリ ウム，牛胎児血清を加えたものを，また，胸腺細胞、マク ロファージの培養には，RPMI-1640（日水製薬 K.K.) に同量のベニシリン，重炭酸ナトリウム，10\%FBSを加 えたものを用いた。

\section{3. 培蓝方法}

採取した尰瘍組織を直ちに眼科用ハサミにて $1 \mathrm{~mm}$ 角 大以下に細切し, $60 \mathrm{~mm}$ プラスチックプレート(Falcon, USA）に植え込み，組織片培崶法による培養を行った. 培養はすべて $95 \%$ 空気, $5 \% \mathrm{CO}_{2}, 37^{\circ} \mathrm{C}$ の条件下に TH-HER 型インキュベーター（平沢製作所）中で静監 培盖を行った。

初代培養期間中の培養液の 交換は, 1 週間に 2 回 と し, 3 回目までの培養液には $2.0 \mu \mathrm{g} / \mathrm{ml}$ のファンギソ ン (Flow Lab. USA) を添加した。継代培養は, 原則 として 5 日に1回とし, 細胞を $\mathrm{Ca}^{++}, \mathrm{Mg}^{++}$脱リン酸 緩衝塩溶液 (PBS $(-)$ ) にて洗浄後, $0.02 \%$ エチレンシ アミン四酢酸を含む0.1\%トリプシン溶液（EDTA-トリ プシン）を， $37^{\circ} \mathrm{C}$ で約 3 分間作用させて絊胞分散し行 
った.

\section{4. 細胞增殖能の模穼}

対数増殖期にある細胞を EDTAートリブンンで分散 後, 24 well ブラスチックフレート (Corning, USA) に 1 well に $2 \times 10^{4}$ 個の細胞を植え込んだ。

4 well を1群として各種㵀度の FBS あるいは牛新生 児血清 (NCS, M.A. Bioproduct, USA) を加文て培费 し，2 日目から10日目までの生細胞数をCoulter Counter (Coulter Electronics, England) にて算出した。

\section{5. 染色体数の模䨛}

対数增殖期にある細胞の培爱液中に, $0.1 \mu \mathrm{g} / \mathrm{ml}$ のコ ルセミド (Sigma, USA) を加え4 時間培蚨した後， EDTAートリブシンにて細胞を単した。この細胞に 20 分間低張液 $(0.075 \mathrm{M} \mathrm{KCI})$ を作用させ，その後，カル ノフ夜（メタノール：水酶酸 $=3: 1$ ）にて固定した。

固定後すみやかに風乾し，ギムザ染色を施し，光学顕 微鏡䚁察および写真掫影を行い染色体数を算定した ${ }^{22}$.

\section{6. ヌードマウスへの移植}

Laminar Flow Iso Rack（三基科学工業 K.K.) 中で specific pathogen free の条件下に飼育されたヌードマ ウス (BALB/c nu/nu 5 週龄早日本クレアK.K.) の背 部皮下に $1 \times 10^{7}$ 個の細胞を接種した。形成された腫瘤 は10\%ホルマリン緩衡夜にて固定し，バラフィン包埋し た後, 薄切し, H-E 染色を施し光学䫒徽鏡にて䚁察し た.

\section{7. インターロイキン-1（IL-1）様物澌の産生に関す 了検索}

1）培養上清の調整

DMEM (10\% FBS) $3 \mathrm{~m} l$ 中に $2 \times 10^{5}$ 個の細胞を浮 遊させ, $60 \mathrm{~mm}$ dish に植え込んた。. 培養後 1 ～9 日目の 上清を採取し, $0.22 \mu \mathrm{m}$ MILEX-GV Filter Unit (日 本ミリポフ工業 K.K.） にて滤過後，IL-1 活性を測定 した.

2) Thymocyte Proliferation Assay

Thymocyte proliferation assay は, Luger $ら^{9)}$ の方法 に準じて行った。すすなわち，LPS 不応系である C 3 H/ HeNCrj マウス（日本チャールズリバーK.K.）より胸 腺細胞を採取した。単離した細胞を $1 \%$ FBS, $5 \times 10^{-5}$ M 2-メルカプトェタノール (2-ME, Sigma, USA) を加えた RPMI 中に浮遊させ， $1 \times 10^{6} / 150 \mu \mathrm{l} /$ well と なるように 96 well plate (Corning, USA) に添加し た. 1 群を 4 well とし，これに，それぞれ試料 $50 \mu l$ および $1.0 \mu \mathrm{g} / \mathrm{ml}$ の PHA を加え72時間培羕した。最 後の16時間で $0.5 \mu \mathrm{Ci} /$ well の [methyl- ${ }^{3} \mathrm{H}$ ] Thymidine ( $\left[{ }^{3} \mathrm{H}\right]-\mathrm{TdR}$, Amersham International plc, England) により細胞をラベルした，ラベル後, PBS (一) で胸腺 細胞を 3 回洗浄し，細胞に取り込まれた ${ }^{3} \mathrm{H}$ 活性を液体 シンチレーションカウンターにより測定した.

3) Fibroblast Proliferation Assay

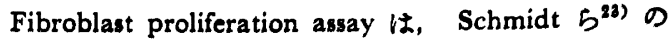
方法に従った，IL-1 活性の测定に用いた線維芽細胸は 口唇裂手術時の余剩口居組織の培慈に上り得た。継代 2 ～ 5 代の線維芽細胞を DMEM (10\% FBS) 中浮 拈させ， 96 well plate $K 5 \times 10^{8} / 150 \mu l /$ well 植え込ん た，24時䦌培善の後 $50 \mu l$ の武料を加え，さらに 48 時

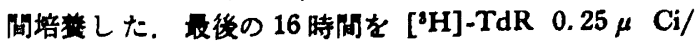
well でラペルした後，PBS（一）にて各 well を洗浄， 絧胞に取り込まれた 'H 活性を液体シンチレーシェン カウンターにて测定した。

なお，IL-1 活性はすべて対照を1とした比で表した。

4) Gel Filtration К上る分析

i ）ヒトマクロファージ IL-1 の㬐

正常の成人男性より採取した $50 \mathrm{ml}$ の末梢血より竞

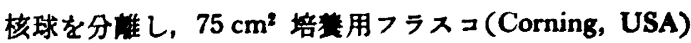
にて2 時間培爰し、フラスコに吸着した細胞をマクロフ フーシシフラクションとした。 これに, $40 \mathrm{ml}$ RPMI, 2 $\times 10^{-5} \mathrm{M}$ 2-ME, $1 \% \mathrm{FBS}, 50 \mu \mathrm{g} / \mathrm{ml}$ シリカ,そして $10 \mu \mathrm{g} / \mathrm{m} l$ LPS (DIFCO Lab. USA) をそれぞれ加え， さらに 2 日培善し上清を採取した。こらして得られた 上清 $400 \mathrm{ml}$ を集め $0.22 \mu \mathrm{m}$ MILLEX-GV Filter Unit にて滤過し，硫安分画に上り70\%酔和画分を採取， これをリン酸㣪街塩溶液 (PBS(+))に対して透析し， 試料とした。

\section{ii）培着上清の調整}

Nakata-1 細胞 $1 \times 10^{6}$ 個を $10 \mathrm{ml}$ の DMEM (10\% FBS) 中に浮遊させ, $10 \mathrm{~cm}$ plastic dish (Corning, USA）に植え込み，5 日間培養の後上清を採取した。 $500 \mathrm{ml}$ の上清を集め，硫安分画により $70 \%$ 的和画分を 採取, これを $0.02 \mathrm{M} \mathrm{NaPB}(\mathrm{pH} 7.4)$ に対して透析 した。これに，同じ得推で平得化した pack volume $50 \mathrm{ml}$ の DEAE Sephacel を加え， $4^{\circ} \mathrm{C} て ゙ 1$ 時間提汼


着フラクションを採取した占).得られた滤液を DIAFLO Ultrafilter Membrane YM-10 (Amicon クレースジャ パン K.K.) を用いた限外清過法により，約 $1 \mathrm{ml}$ まで 浸縮し, PBS (十) に対して透析した.

iii) Gel Filtration

浱縮した試料約 $1 \mathrm{ml}$ を $0.22 \mu \mathrm{m}$ MILLEX-GV Fil-

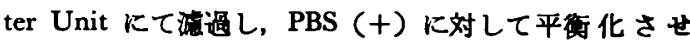
た $2.6 \times 90 \mathrm{~cm}$ Sephacryl S-200 (Pharmacia, Sweden) カラムにかけた。流速は, $16 \mathrm{ml} / \mathrm{h}$ とし, 溶出した各 $3 \mathrm{ml}$ の fraction を回収した。 各 fraction は, $0.22 \mu$ m MILLEX-GV Filter Unit により腹過滅菌し, thymocyte proliferation assay により IL-1 活性を測定し た. カラムの caribration には, Bovine Serum Alb$\min (6.7 \mathrm{KD})$, Obalbmin (4.3 KD), Chymotrypsinogen A (2.5 KD), Ribonuclease A (1.37 KD) (Gel Filtration Caribraion Kit, Pharmacia, Sweden)を用い 
た.

$$
\text { 結 果 }
$$

\section{1. 培養経週}

写真1は Nakata-1 細胞を得た原発部哃瘦で，その組

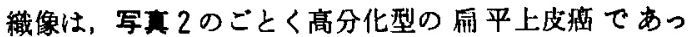
た。写直了は，初代培養時の Nakata-1 稩胞を示したも ので，畽場塊より多角形の上皮槏紐胞の增殖が見られ た。 上皮様細胞が full sheet に達した昭和60年 2 月曰日 第 1 回目の継代を行い，以後原則として 5 日に 1 回の継 代を行った，写真 4 は，継代25代の Nakata-1 細胞の㩆 微鏡像で，多角形の上皮様細胞がスられた。

\section{2. 細胞增殖能}

図 1，2に継代25代，72代の Nakata-1 細胞の增殖曲 線を示した，いずれす $10 \%$ FBS を加えた時，最大の增 殖能を示したが，72代においては，1％ FBSを加えた 時でも10\% FBS と変わらない增殖能を示した，継代 25

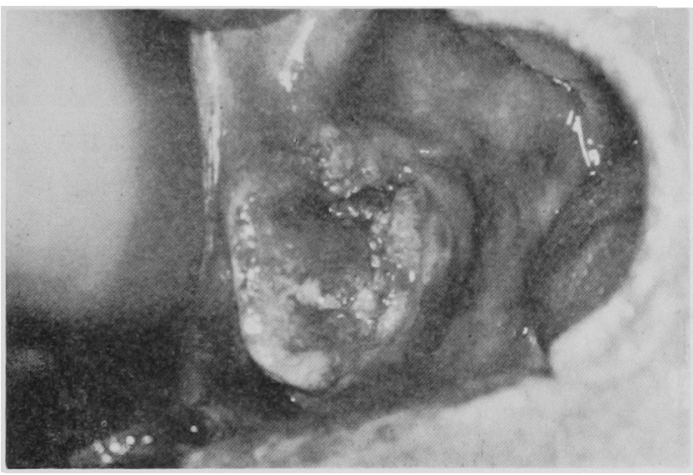

写真 1 Nakata-1を得た原発部尰㷎

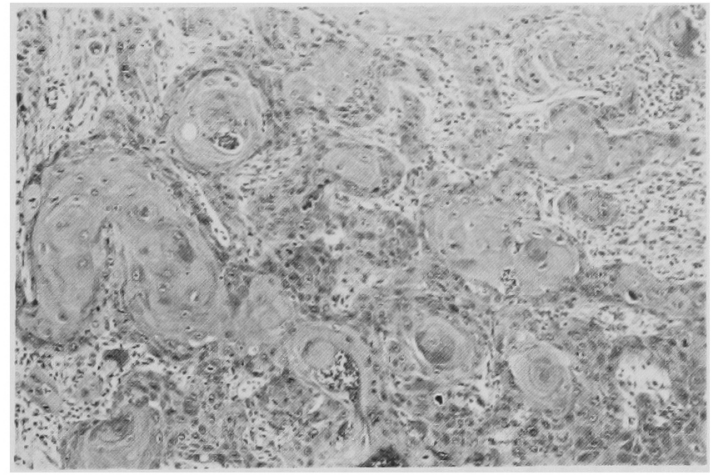

写真 2 原発部尰袍の組織像 $(\times 100)$

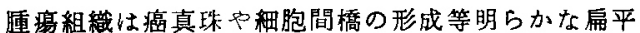
上皮の性格を示し，畽湟細胞には，核や細胞の大小 不同，外核の細胞の出現や異型核分裂像の出現等か なり強い細胞異型性が鼬察される。

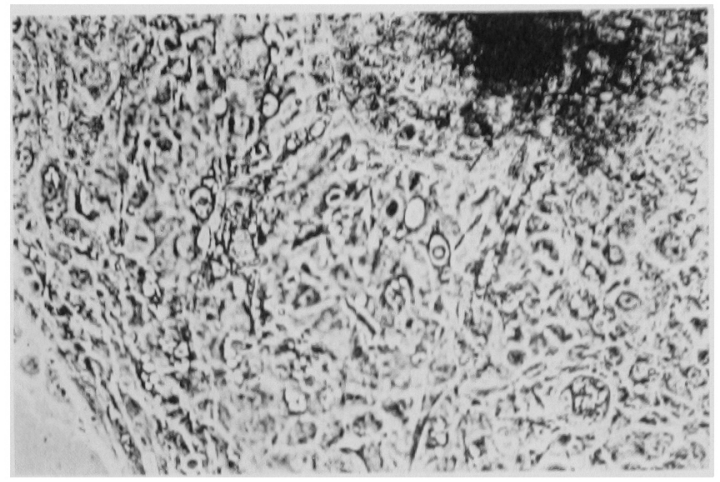

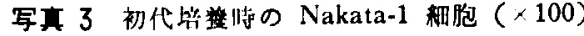

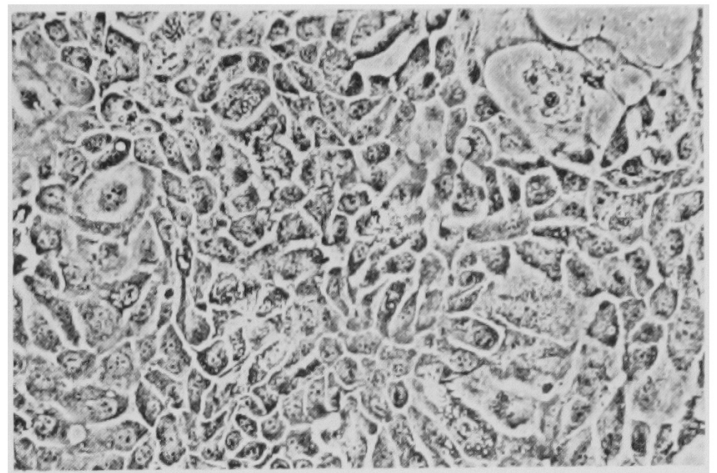

写真 4 秤代 25 代の Nakata-1 細胞 $(\times 100)$



図 1 継代25代における稩胞增殖曲線 


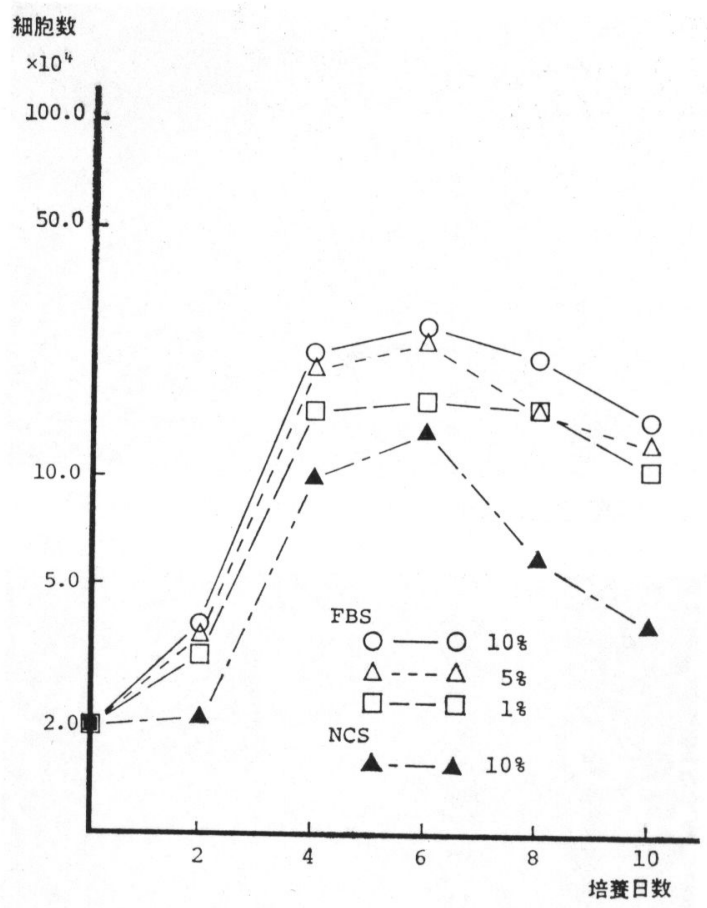

図 2 継代72代に打ける細胞增殖曲線
代での細胞倍加時間は, 21.8時間, 72 代では18.6時間で あった。

\section{3. 染色体数}

図了は, 継代11代 Nakata-1 細胞の染色体数の分布を 示したもので, 染色体数は55〜153 の範囲に分布し，モ ードは85であった。

継代72代では, 染色体数は 54 157 の範囲に分布し, モードは73であった。

\section{4. ヌードマウスへの移植}

写真 5 は継代 9 代の Nakata-1 細胞のヌードマウス移

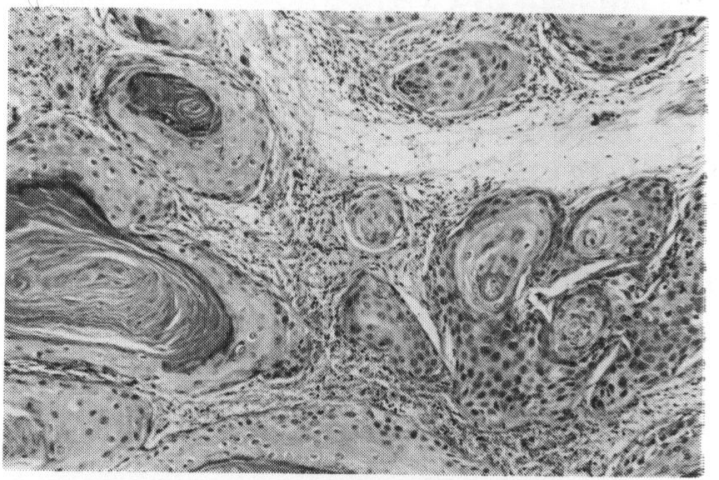

写真 5 ヌードマウス移植腫瘍の組織像 $(\times 100)$

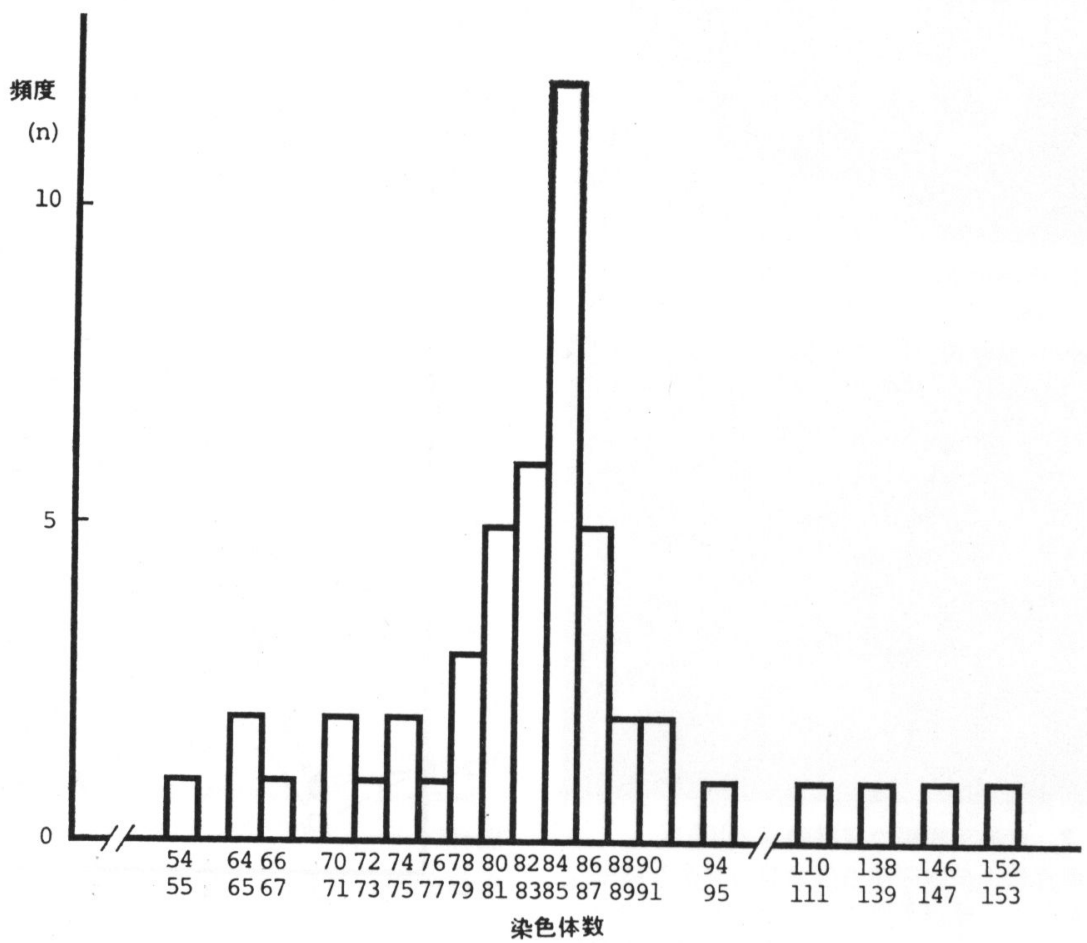

図３継代11代に招计る染色体数の分布 
植腫痔の組織像で，原発然に似た角化㑯向の強い，細胞 間橋の明瞭な高分化型の扁平上皮癌であった。

\section{5. 培举上清中の IL-1 活性について}

Nakata-1 細胞の 培绶上消中の IL-1 活 性は, thymocyte proliferation assay においては, 5 日目にはぼ

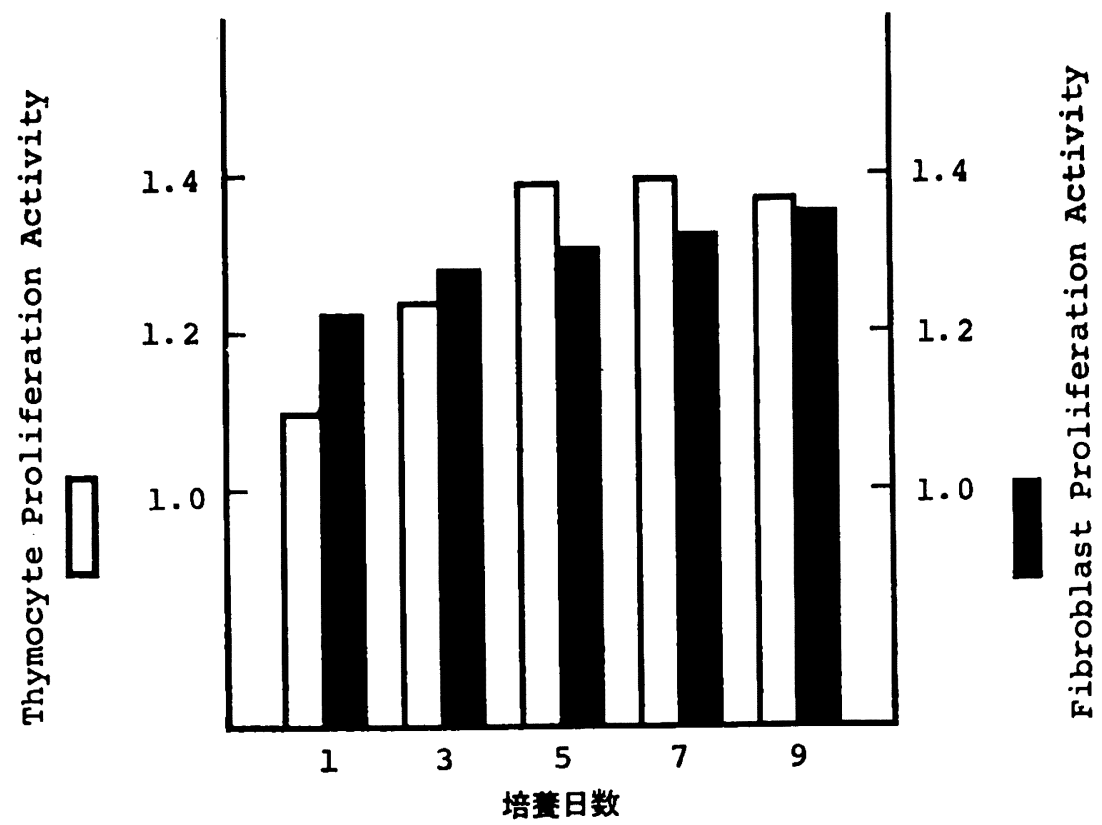

图 4 培善上消中の IL-1 活性の变動

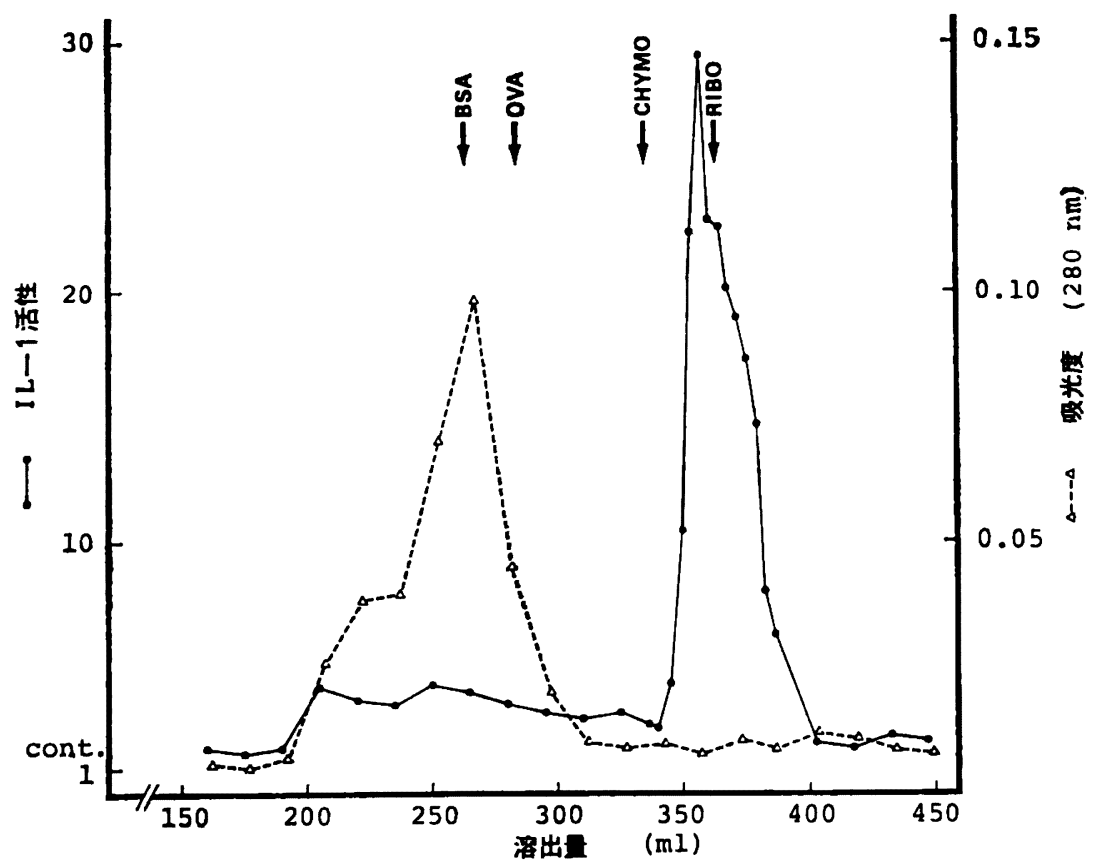

図 5 ヒトマクロファージより得られた IL-1 のゲル懑過に拈ける IL-1 活性の溶出ハターン 


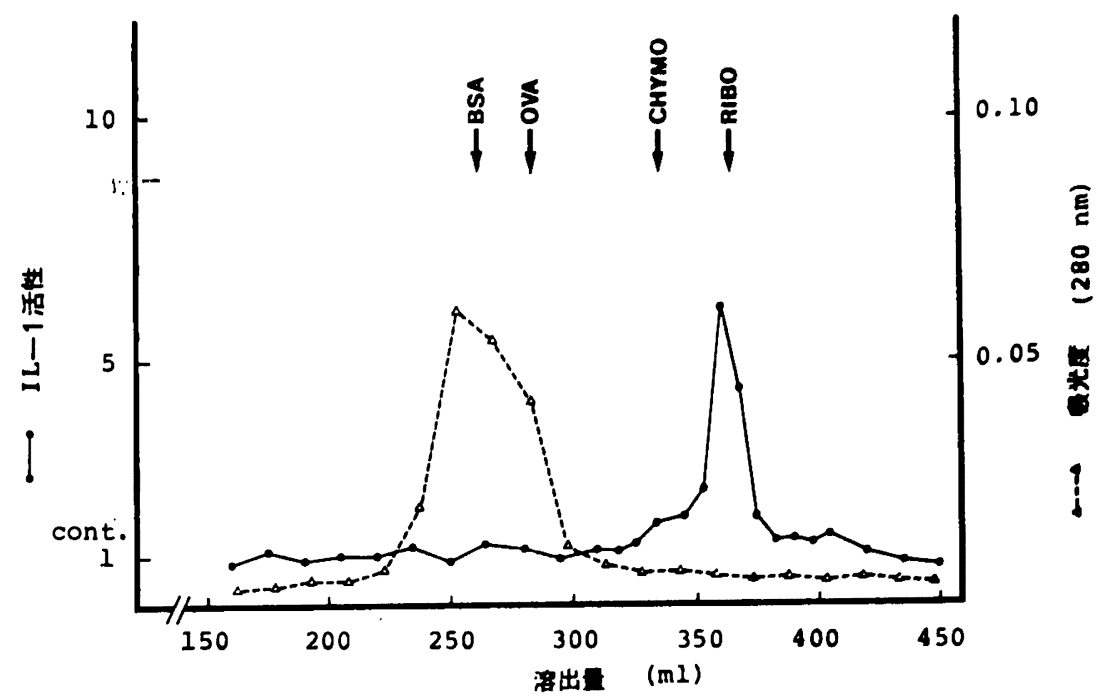

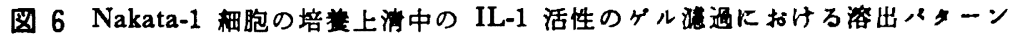

ピークに達し，9日目では，減少した，fibroblast proliferation assay においては，9日目まで徐々に增加し た（図 4).

\section{Gel Filtration による分析}

图5は，マクロファージより得られた IL-1 のゲル滤 過での IL-1 活性の溶出パターンを示したもので, IL-1 活性のピークは, 分子量約15,000付近に溶出した。 Nakata-1 の培養上清中の IL-1 活性は, マクロフーー - シ IL-1 と同様の溶出パーンを示した（図6）.

\section{考察}

培養技術の発達とともに，多くの細胞株の樹立が報告 されている. 特に悪性腫疡由来のものについては, 種々 の葴器腫瘍由来のものが樹立されている25,28). 口腔項域 由来のものは Moore 5の Hep 3 細胞 ${ }^{38)}$ に始まるが, 文献的報告のあるものは少ない、28 45)

Nakata-1 細胞は, 大星 ${ }^{46)}$, 山田 ${ }^{42)}$ らがあげている培 養細胞の持つ特徽のらちで，(1）安定した増殖能（2） 染色体構成の異数性 (3) in vivo での腫焬形成, といっ た条件を満たしていた。

IL-1 様物質の上皮細胞による産生は Luger らによ り示され゙), Epidermal cell-derived Thymocyte Activating Factor (ETAF) と名づけられた。この物質の IL-1 との類似性は Luger ら ${ }^{47)}$ により示されている. この ETAF を始めとして多くの正常細胞が， IL-1 様 の物質を産生することが報告されている。さらに， Luger ら ${ }^{19)}$ はケラチノサイト由来の覀性腫瘍である扁 平上皮癌の 1 例で IL-1 様物質が産生されることを示し た，その後，覀性腫湯においてはメラノーママ21)，神経䢧

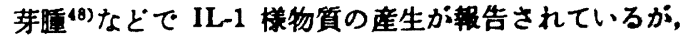
口腔領域扁平上皮舴による産生の啹告はない。

IL-1 の作用は多徨にわたるか，一般に，兔度系細胞 の活性化，炎症反応の促進などがあげられる。この様な 物質を睡湯細胞が産生することは，非常に與味深いこと である。

Nakata-1 細胞の産生する物質は, fibroblast prolife ration assay および thymocyte proliferation assay の兩 者に活性を示し，しかもこの活性はヒトマクロフォー シ IL-1 と Sephacryl S-200 カラムによるゲル 澢遣 K おいてる同様の举琺を示すことから，この物質が IL-1 に近いるのと考えられた。

IL-1 の抗隀被作用 ${ }^{50)}$ の機序は T cell に対して Interferon, IL-2 などの液性因子の産生, T cell の IL-2 receptor $の$ 発現, cytotoxic $\mathrm{T}$ cell $の$ 䛻導, natural killer cell の活性化, 単球の抗連清活性の増強など(日)が考えら れている，また，IL-1 は，畽㻛細胞に対して直接，cytostatic あるいは cytotoxic に㤼くとすいわれているら1).

しかしながら，IL-1 は線䊒芽細胞に対して Prostaglandins (PGs), 特に $\mathrm{PGE}_{2}$ を産生させる作用を持 $つ^{52)}$. IL-1 P PGE 2 は骨吸収作用を持っており 53,54$)$,

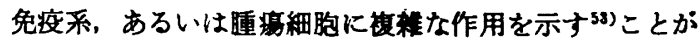
知られている，また，PGE

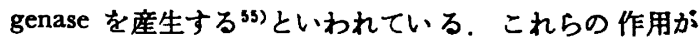
局所における腫瘦細胞の浸潤，增殖に関与していること む考えられる。

一方, メラノーマや肝細胞㾔の細胞に IL-1 に対する receptor が存在することが報告されている56) いまた， IL-1 が腫场細胞の増殖を促進する事実は認められてい ないが，腫瘍細胞の産生する IL-1 あるいは， IL-1 様 


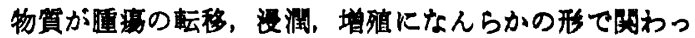
ている可能性は十分に考えられる。

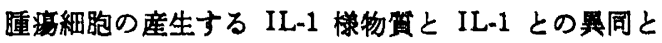
ともに，このよらな物筫と尰就との関係を明らかにする ことは，癌と免疫との関係を明らかにする上で重要な踝 題と考えられる。

\section{結晤}

煩粘膜扁平上皮税上り株化細胞（Nakata-1）の樹立に 成功した．同細胞の培養上清中にはマクロファージより 得られた IL-1 と一致した性筫を示す IL-1 活性が存在 し，Nakata-1 細胞が IL-1 様物質を 産生する 可能性が 示された。

\section{引用文献}

1) Sporn, G.J. and Tudaro, M.B.: Autocrine secration and malignant transformation of cells. N Engl J Med 303: 878-880 1980.

2) Massague, J.: The transforming growth factors. Tredns Biol Sci 10: 237-240 1985.

3）梅田 誠：Transforming growth factor「細胞

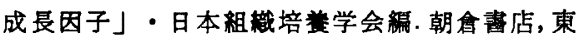
京, 1984, 99-105頁.

4) Vallee, B.L., Riordan, J.F., et al.: Tumorderived angiogenesis factor from rat Walker 256 carcinoma: an experimental investigation and review. Fxperientia 41: 1-142 1985.

5) Hyodo, T., Megyesi, K., et al.: Adrenocortical carcinoma and hypoglycemia: Evidence for production of nonsuppressible insulin-like activity by the tumor. J Clin Endocrinol Metab 44: 1175-1184 1977.

6) Pavelic, K.: Aplastic carcinoma in diabetic mice: Hyperglycemia-suppressed proliferation rate and insulin synthesis by tumor cells. J Natl Cancer Inst 62: 139-141 1979.

7) Dinarello, C.A.. Interleukin-1. Rev Infect Dis 6: 51-95 1984 .

8) Kampschmidt, R.F.: The numerous postulated biological manifestations of interleukin-1. J Leukocyte Biol 36: 341-355 1984.

9) Luger, T.A., Stadler, B.M, et al.: Epidermal cell (keratinocyte)-derived thymocyte-activating factor (ETAF). J Immunol 127: 149314981981.

10) Luger, T.A. and Oppenheim, J.J.: Characteristics interleukin 1 and epidermal cell-derived thymocyte activating factor. Adv Inflammation Res 5: 1-25 1983.

11) Sauder, D.N., Carter, C.S., et al.: Epidermal cell production of thymocyte activating factor
(ETAF). J Invest Dermatol 79: 34-39 1982.

12) Sauder, D.N., Dinarello, C.A., et al.: Langerhans cell production of interleukin-1. J Invest Dermatol 82: 605-607 1984.

13) Fontana, A., Kristensen, F., et al.: Production of prostaglandin $E$ and an interleukin-1 like factor by cultured astrocytes and

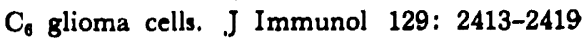
1982.

14) Miossec, P., Cavender, D., et al.: Production of interleukin 1 by human endothelial cells. J Immunol 136: 2486-2491 1986.

15) Grabner, G., Luger, T.A., et al.: Corneal epithelial cell-derived thymocyte-activating factor (CETAF). Invest Ophthalmol Vis Sci 23: 757-763 1982.

16) Iribe, H., Koga, T., et al.. Stimulating effect of MDP and its adjuvant-active anlaogues on guinea pig fibroblasts for the production of thymocyte-activating factor. J Exp Med 157: 2190-2195 1983.

17) Okai, Y., Tashiro, H., et al.: 3T3 fibroblasts are stimulated by 12-0-tetradecanoyl-phorbol-13acetate to produce thymocyte-activating factors. FEBS Lett 142: 93-95 1982.

18) Hauser, C., Saurat, J. H., et al.: Cultured human epidermis cells produce cell-associated interleukin-1 like prostaglandin $E_{2^{-}}$and collagenase-stimulating factors. Biochem Biopys Acta 840: 350-355 1985.

19) Luger, T.A., Stadler, B.M., et al.: Characteristics of an epidermal cell thymocyteactivating factor (ETAF) produced by human epidermal cells and a human squamous cell carcinoma cell line. J Invest Dermatol 81: 187-193 1983.

20) Sauder, D.N., Mounessa, N.L., et al.: Chemotactic cytokine: The role of leukocytic pyrogen and epidermal cell thymocyte-activating factor in neutrophil chemotaxis. $J$ Immunol 132: 828-832 1984.

21) Kokoschka, E.M., Luger, T.A., et al.: MeIanoma cell production of an interleukin 1like thymocyte activating factor. Arch Dermatol Res 276: 267 (Abstr) 1984.

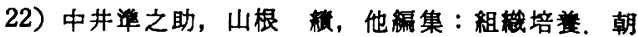
倉書店, 東京, 1976, 217-223頁。

23) Schmidt, J.A., Mizel, S.B., et al.: Interleukin 1 , a potential regulator of fibroblast proliferation. J Immunol 128: 2177-2182 1982.

24）松島綱治：線䑾芽細胞を用いたインターロイキ ン 1 (Interleukin 1) の定量. 免疫实駼操作 法 V、日本免疫学会糄，1983，3907-3912頁。

25）関口守正, 鈴木利夫：わが国で培隻樹立, 䑾持

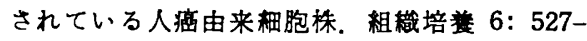
5481980. 
26）佐藤 博：日本で䊒持されている可移柱性䐈满

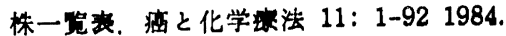

27) Moore, A.E., Sabachewsky, L., et al.: Culture characteristics of four permanent lines of human cancer cells. Cancer Res 5: 5986021955.

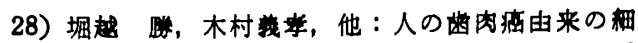
胞株の樹立. (第一垠). 日外誌 $20: 10-16$ 1975.


项部のリソパ䬣耺移柴よりえられた新梱胞株 (HSC-1) について。回科詰 24: 61-74 1975.

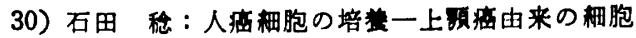
株について一。耳年 81: 588-603 1978.

31）小池正夫，五木田利明：ヒト肉㾞由来の細胞 株（MK-1）の樹立とその性状. 日口外誌 26: 1481-1489 1980.

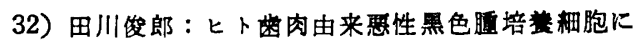

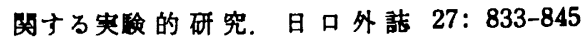
1981.

33）猪川勉：頭頸部扁平上皮程細胞に対するリン ：球の湅胞障客性の研究一1. 頭新部扁平上皮

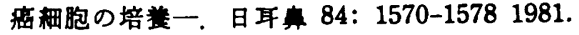

34）小松正隆，浦出隆裕：著明な角化㑯向をるつ上 顎扁平上皮癌由来株化細胞の樹立. 日口外誌 29: 1243-1248 1983.

35）菱田市和：放射線炤射を5けたヒト頻下唾液腺 からの造腫晹性䎩胞の分離。阪大荬誌 29:36631984

36）百瀬文雄, 平田章二, 他：3つの口腔扁平上皮 癌由来耕胞の性状について。 口科誌 35：4854961986.

37) Okabe, T., Sato, N., et al.: Establishment and characterization of a human cancer cell line that produces human colony stimulating factor. Cancer Res 38: 3910-3917 1978.

38) Eagle, H.: Propagation in a fluid medium of a human epidermoid carcinoma, strain KB. (21811). Proc Soc Exp Biol Med 89: 362-364 1955.

39) Zenner, H.P., Lehner, W., et al.: Establishment of carcinoma cell lines from larynx and submandibular gland. Arch Otorhinolaryngol 225: 269-277 1979.

40) Rheinwald, J.G. and Beckett, M.A.: Tumorigenic keratinocyte lines requiring anchorage and fibroblast support cultured from human squamous cell carcinomas. Cancer Res 41: 1657-1663 1981.

41) Easty, D.M., Easty, G.C., et al.: Ten human carcinoma cell lines derived from squamous carcinomas of the head and neck. Br J Cancer 43: 772-785 1981.

42) Easty, D.M., Easty, G.C., et al.: Five human tumour cell lines derived from a primary squamous carcininoma of the tongue, two subsequent local recurrences and two nodal metastases. $\mathrm{Br} J$ Cancer 44: $363-370$ 1981.

43) Zenner, H.P., Herrmann, I.F., et al.: Head and neck carcinoma models. In vivo reproduction in athymic mice and in vilro culture. Acta Otolaryngol 95: 371-381 1983.

44) Huang, D.P., Ho, J.H.C., et al.: Establishment of a cell line (NPC/HK 1) from a differentiated squamous carcinoma of the nasopharynx. Int J Cancer 26: 127-132 1980.

45) Nishihira, T., Kasai, M., et al.: Charactoristics of two cell lines (TE-1 and TE-2) do rived from human squamous cell carcinoma of the esophagus. Gann 70: 575-584 1979.

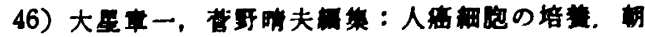

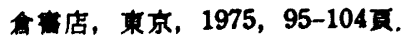

47) Luger, T.A., Atadler, B.M., et al.: Murine epidermal cell-derived thymocyte-activating factor resembles murine interleukin 1 . J Immunol 128: 2147-2152 1982.

48) Fontana, A., Hengartner, H., et al.: Glioblastoma cells release interleukin 1 and factors inhibiting interleukin 2 mediated effects. J Immunol 132: 1837-1844 1984.

49) Oppenheim, J. J., Kovacs, E. J., et al.: There is more than one interleukin 1. Immunology Today 7: 45-56 1986.

50) Onozaki, K., Matsushima, K., et al.: Role of interleukin-1 in promoting human monocyte-mediated tumor cytotoxicity. J Immunol 135: 314-320 1895.

51) Onozaki, K., Matsushima, K., et al.: Human interleukin 1 is a cytocidal factor for several tumor cell lines. J Immunol 135: 3962 39681985.

52）中野昌康：内毒素の生物活性一兔度采に対する 作用 (内毒素一その構造と活性). 医齿薬出肘, 東京, 1983，259-288頁.

53) Chambers, T. J., McSheehy, P.M.J., et al.: The effect of calcium-regulating hormons and prostaglandins on bone resorption by osteoclasts disaggregated from neonatal rabbit bones. Endocrinol 116: 234-239 1985.

54) Thomson, B.M., Saklatvala, J., et al.: Osteoblasts mediate interleukin 1 stimulation of bone resorption by rat osteoclasts. J Exp Med 164: 104-112 1986.

55) Postlethwaite, A.E., Lachman, L.B., et al.: Interleukin I stimulation of collagenase production by cultured fibroblasts. J Exp Med 157: 801-806 1983.

56) Dower, S.K., Kronheim, S.R., et al.: Detection and characterization of high affinity plasma membrane receptors for human interleukin 1. J Exp Med 162: 501-515 1985. 